\title{
OPEN EDUCATIONAL RESOURCES
}

\author{
Mokhamad Syaifudin \\ Email:msyaifudin@gmail.com \\ Universitas Islam Negeri Sunan Ampel Surabaya
}

\begin{abstract}
In this article a brief exposition of what open education resources is presented. The article begins by presenting the general idea of what OER is then move to the possible benefits and challenges to the OER for teaching and learning. Efforts to address the possible challenges in OER are also presented as well as the places where OER can be sought. In the end of the article samples of possible scenario of how to use the OER for teaching learning process are also detailed.
\end{abstract}

Keywords: open educational resources, benefits and challenges, teaching and learning

\section{WHAT IS IT?}

Open Educational Resources (OER) are documents and media which are freely accessible for use in teaching, learning and even research. They are usually given open licences meaning that users of the resources are free to obtain, read, modify, and distribute them for lawful purposes(Atkins, Brown, \& Hammond, 2007; Friesen, 2013; OECD, 2007). OER which are normally created by various people from around the world, can be found in various forms such as full courses, course modules, syllabi, lectures, assignments, course materials, videos, games and simulations (Atkins et al., 2007; McGill, 2013; White et al., 2011).

The advance of information technology such as today's Internet services has made the OER are ubiquitous. More people are willing to create, share, obtain, or even just use or modify the easily accessible digital materials (White, Manton, \& Warren, 2011).

The term OER was firstly introduced in the UNESCO forum in 2002 (OECD, 2007) and has been attracted educators around the world since then. Nowadays, the OER concept has been bringing about some major revolution in how people can obtain their knowledge. If they want free course from top education providers, for 
example, they can just easily go to some free open course work (OCW) providers on the Internet such as http://www.coursera.org, http://www.edX.org, https://www. futurelearn.com/, http://online.stanford.edu/courses and still many more that can be easily found online. In addition to OCW, people nowadays can easily search knowledge through using search engines that are also another breakthrough in the OER concepts. Teachers, students, researchers can easily research on certain topics by using search engines such as http://www.google.com, http://www.bing.com or http://www. yahoo.com. If they want more visual explanation the availability of video sharing websites such as http://www.youtube.com, http://www.vidio. com, http://www.vimeo.com are few alternatives to obtain knowledge through audiovisual presentation.

\section{IN WHAT WAY OER CAN BENEFIT PEOPLE TODAY}

The availability of today's OER can benefit many parties such as teachers, students, researchers, material developers, parents and probably still many more. Unlike it used to be, when teachers were still the main information provider in the classroom, and the only information available in the classroom can be obtained mainly from them or from the available textbooks. Today, any information can be accessed by students from anyone, anywhere and from any sources from around the world. Interestingly, they can do it only by the touch of their fingers on their internet-connected mobile devices. The Information are no longer presented before them in static, black and white text or images but they are in more colorful, animated, or even in the form of audio and video.

Teachers are no longer limited by the availability of blackboard and the dusty chalks to present their materials and to invite students to collaboratively work in front of the classroom, they can nowadays motivate them by presenting materials in a more engaging, and colorful audio visual materials that can either be self-created by them or obtained or shared from the Internet. World class and up-to-date materials are at their fingertips to discus or share with their students. Teachers' time to prepare materials are nowadays tend to be substituted by selecting materials from the available OER as well as 
modifying it to suit their set educational goal. In short, today with the availability of OER, teachers can dedicate more time to selecting good and appropriate OER and finding ways of how to enable them to be used in their instruction.

However, it is suggested that for teachers to make use of OER, they should not merely assume that they can easily and rapidly develop courses or prepare materials. On the contrary, they should consider spending more time on assessing how the OER can be used to enhance their teaching and learning practice (White et al., 2011). They should be very keen in selecting which OER that can help enriching and varying their students learning experiences. Also, they should then consider how they would OER into their teaching practice?

White et al. (2011) identify various ways that teachers make use of OER in their instruction. They found that thirty nine percent of the teacher respondents use OER as is without any modification, $28 \%$ use OER but with modification and adaptation here and there to suit their teaching/students' needs, 22\%use the OER without modification but provide the introduction or guidance for use with the OER materials, and $11 \%$ use OER only as source of ideas that they can later use to develop their own content for their own teaching purposes. Deciding on how to use the OER actually depends on many factors such as technical knowledge and skills, technology compatibility, learning needs, curriculum goals etc. Another factor that determines the use of OER is whether or not the OER wanted is easily discoverable. This discoverability aspect is actually on one of the challenges that OER creators or users have to address when working with OER (Thakrar et al., 2009; White et al., 2011). So far, OER users usually find OER through search engines, trusted sites, and OER or institutional repositories (White et al., 2011). More challenges will be presented in the OER challenges section below.

\section{Possible Benefits of OER for teachers and learners}

Using OER offers both teachers and learners benefits and challenges. Some benefits of using OER for teachers are that they are ready and freely available for use. It means that teachers can instantly use them without any cost. Many of the OER are often regularly 
updated which means users can always have up-to-date learning materials. However updating can sometimes cause problems of dysfunctional links. Therefore, authors and users should be very careful. Since the OER are in the form of digital materials and available mostly online, they can be easily translated from one language to others by using web-based translators, or other translating tools which are nowadays easily accessible ("Benefits of open educational practices and resources," 2014). Other benefits of OER as mentioned by the OECD (2007) and Hodgkinson-Williams (2010) are related to economic reasons, publicity reasons, personal satisfaction, as well as for increasing teachers' personal reputations

Some other benefits of OER are mentioned by Wheeler (2010) he said that OER today promote digital competencies because many OER in the form of web-based authoring tools such as comic maker (e.g. http://www.toondoo.com, http://www.pixton.com), info graphic maker (e.g. http://www.piktochart.com, http://vizualize. me/, http://www.easel.ly/), online presentation tools (e.g. http://www.movenote.com, http://videoscribe.co, https://www. powtoon.com/), educational games (e.g. http://www. learninggamesforkids.com/, http://www.thinkfun.com/playonline/) available today facilitate learners to develop creativity and critical thinking. Further, He mentions that OER also support lifelong learning because people can always access OER materials anytime and anywhere as long as they are connected to the Internet. Let's take an example of video sharing websites that are free to access. People can always share knowledge and learn new knowledge through this site. Moreover, the OER potentially offer wider range of subjects and topics to learn to wider groups of audiences because they are placed on the Internet.

More benefits of the OER suggested by few authors are summarized in the following Table 1. Learning from such suggested benefits would certainly help teachers to understand what is actually offered by OER and how it will possibly be beneficial for assisting in teaching and learning process. 
Table 1 Possible benefits of OER for teaching and learning process

\begin{tabular}{|c|c|}
\hline Authors & Benefits \\
\hline $\begin{array}{l}\text { Caswell, Henson, } \\
\text { Jensen, and Wiley } \\
(2008)\end{array}$ & $\begin{array}{l}\text { - Accessible by wider audiences at no cost or } \\
\text { just a little } \\
\text { - Enablers to universal rights to education } \\
\text { - Making distance education a tool for social } \\
\text { transformation } \\
\text { - Faculty members can easily shares their } \\
\text { work with others }\end{array}$ \\
\hline $\begin{array}{l}\text { Hodgkinson- } \\
\text { Williams (2010) }\end{array}$ & $\begin{array}{l}\text { - Learners can easily access materials from } \\
\text { around the world } \\
\text { - Promoting informal learning } \\
\text { - Teachers can preserve the records of their } \\
\text { teaching and others can build upon them } \\
\text { - Teachers can gain reputation by being } \\
\text { online and share their work } \\
\text { - Education institutions may improve their } \\
\text { recruitment because students can easily } \\
\text { find them } \\
\text { - Promoting lifelong learning }\end{array}$ \\
\hline $\begin{array}{l}\text { Thakrar, Wolfenden, } \\
\text { and Zinn (2009) }\end{array}$ & $\begin{array}{l}\text { - Possible exposure to authentic samples (e.g. } \\
\text { vocabularies by native speakers) } \\
\text { - Representing multinational ideas } \\
\text { - Democratizing access to knowledge } \\
\text { - Promoting communities of practice }\end{array}$ \\
\hline
\end{tabular}

\section{Possible Challenges when using the OER}

In addition to the benefits, there must be challenges to the OER adaptation in teaching learning process. Few authors, as summarized in Table 2 below, suggest possible challenges that needs be addressed to work on possible solutions so that OER can still be useful for the purpose of teaching and learning despite the challenges. 
Table 2 Possible challenges to the use of OER

\begin{tabular}{ll}
\hline Authors & Challenges \\
\hline $\begin{array}{l}\text { Caswell, } \\
\text { Henson, }\end{array}$ & - Content licensing can be troublesome if used \\
Jensen, and & $\begin{array}{l}\text { with other contents licensed under different } \\
\text { licenses. } \\
\begin{array}{l}\text { Wiley } \\
(2008)\end{array}\end{array}$ \\
\hline $\begin{array}{l}\text { Hodgkinson- } \\
\text { Williams }\end{array}$ & - Hardware reliability and compatibility issues \\
$(2010)$ & - Assuring the shared contents' quality \\
& - Low interest in others' created resources \\
& - Quality assurance and financial sustainability \\
\hline $\begin{array}{l}\text { Thakrar, } \\
\text { Wolfenden, }\end{array}$ & Hardware issues (such the reliability of internet \\
Zinn & connection, printers and other technology- \\
$(2009)$ & - Technological knowledge and skills \\
& - $\begin{array}{l}\text { Discoverability of the OER and adaptability of } \\
\text { the OER }\end{array}$ \\
\hline
\end{tabular}

Those challenges are nowadays seems to have been gradually addressed. Technology related issues for example, has been well addressed by the current development in technology products. The reliability of Internet connection, software compatibility issues, user friendliness of the OER tools are all nowadays getting more updated and improved to suit the needs of the society. More people nowadays live with technology and problems solve their technology relatedissues. The phenomena quickly happen in the society because technology today is no longer supplementary needs in people's daily life rather become primary needs to help people live. A smart phone for example, social media, internet-based chat messenger which all are self-learned by people when utilizing them despite all the complexity that may be offered through features in those technology products.

Another example of challenges to OER that has been currently addressed is the copyright issue. Through the creative common licensing nowadays, OER has been given different creative common 
licensing. The question is probably why OER needs this kind of licensing. Below is a brief explanation of what is creative common licensing is.

\section{Creative Common (CC) Licensing}

OER are surely the products of creative minds. The creator of the OER (usually called Licensor) deserve to claim the right as the owner of the OER work but may gives others (Licensee) licenses to copy, distribute, and make some uses of their work. One way to make that possible to happen is through giving specific licensing which nowadays known as CC licensing. There are few types of creative common licensing. Below is a brief description of the few types of creative commons licensing

\begin{tabular}{|c|c|}
\hline $\begin{array}{l}\text { The first type of CC licensing is the } \\
\text { Attribution licence. Figure } 1 \text { display the } \\
\text { known logo for this type of licensing. This } \\
\text { license means that the licensors offers others } \\
\text { the right to use, reuse, modify and distribute } \\
\text { their work even for commercial purpose, as } \\
\text { long as their names are credited as the } \\
\text { creator of the work. }\end{array}$ & $\begin{array}{l}\text { (9) } \frac{1}{\mathrm{~N}} \\
\text { Attribution } \\
\text { CC BY } \\
\text { Figure } 1 \text { CC License: } \\
\text { CC-BY }\end{array}$ \\
\hline $\begin{array}{l}\text { The second type of CC licensing is } \\
\text { Attribution-ShareAlike licensing (see Figure } \\
\text { 2) for the logo. Similar to the first license, } \\
\text { this type of license adds conditions to the } \\
\text { licensees that they will have to license their } \\
\text { work using the same license to their work if } \\
\text { derivated from the Licensors work }\end{array}$ & 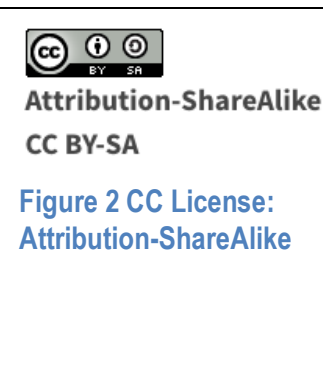 \\
\hline $\begin{array}{l}\text { The third type of the licensing is Attribution- } \\
\text { NoDerivs (see figure } 3 \text { for the known logo of } \\
\text { the license). Using this license, the licensor } \\
\text { of a product give licensee the rights to } \\
\text { redistribute the product to redistribute it }\end{array}$ & 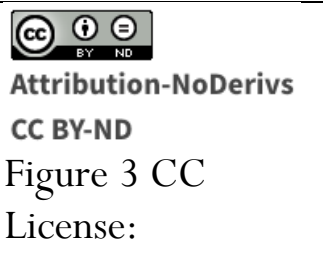 \\
\hline
\end{tabular}




\begin{tabular}{|c|c|}
\hline $\begin{array}{l}\text { commercially or non-commercially as long as } \\
\text { no modification is made to the product and } \\
\text { licensor is credited. }\end{array}$ & $\begin{array}{l}\text { Attribution- } \\
\text { NoDerivs }\end{array}$ \\
\hline $\begin{array}{l}\text { The fourth type of the licensing is the } \\
\text { Attribution-Non Commercial (See figure } 4 \\
\text { for the logo) meaning that the licensor offers } \\
\text { to the licensee to use, reuse, modify and } \\
\text { distribute their product non-commercially. } \\
\text { Though later the licensee has to credit the } \\
\text { creator but he/she does not have to give } \\
\text { similar license to the derivative works. }\end{array}$ & $\begin{array}{l}\text { (c) (1) @) } \\
\text { Attribution-NonCommer } \\
\text { CC BY-NC } \\
\text { Figure 4: CC } \\
\text { License: } \\
\text { Attribution- } \\
\text { NonCommercial }\end{array}$ \\
\hline $\begin{array}{l}\text { The fifth type of the CC licensing is } \\
\text { Attribution-NonCommercial-ShareAlike (see } \\
\text { figure } 5 \text { for the logo). Using this license the } \\
\text { licensor offers to licensee to use, reuse, } \\
\text { modify and distribute their work non- } \\
\text { commercially as long as the licensee credit } \\
\text { the licensor and give the derivative work } \\
\text { identical license. }\end{array}$ & $\begin{array}{l}\text { @) (1)(- } \\
\text { Attribution-NonCommercial-sh } \\
\text { cC BY-NC-SA } \\
\text { Figure } 5 \mathrm{CC} \\
\text { License: } \\
\text { Attribution- } \\
\text { NonCommercial- } \\
\text { ShareAlike }\end{array}$ \\
\hline $\begin{array}{l}\text { The sixth type of CC Licensing is } \\
\text { Attribution-NonCommercial-NoDerivs (See } \\
\text { figure } 6 \text { for the logo). Through this type of } \\
\text { licensing, the licensor give rights to the } \\
\text { licensee to use his work as long as the } \\
\text { licensor is credited, no modification to the } \\
\text { work is made and no commercial use is } \\
\text { done(Commons, 2016) }\end{array}$ & $\begin{array}{l}\text { @D@ } \\
\text { Attribution-NonCommercial-NoDerivs } \\
\text { cc BY-NC-ND } \\
\text { Figure } 6 \mathrm{CC} \\
\text { License: } \\
\text { Attribution- } \\
\text { NonCommercial- } \\
\text { NoDerivs }\end{array}$ \\
\hline
\end{tabular}




\section{WHERE TO ACCESS THE OER}

So far, much effort has been applied by OER enthusiasts to compile OER in the form of annotated links in websites which are either personally or even institutionally maintained. Those websites are organized for different purposes and in various ways. The following Table 3 lists some OER sites that can be useful for finding OER for teachers, students or self-directed learners.

Table 3 Annotated List of OER sites

\begin{tabular}{|c|c|c|}
\hline $\begin{array}{l}\text { Catego } \\
\text { ries }\end{array}$ & URL & Annotation \\
\hline $\begin{array}{l}\text { General } \\
\text { Search } \\
\text { Engines }\end{array}$ & $\begin{array}{l}\text { http: / /www.google.com } \\
\text { http:/ / www.yahoo.com } \\
\text { http: / / www.bing.com } \\
\text { http: / / www.lycos.com/ }\end{array}$ & $\begin{array}{l}\text { People today most probably } \\
\text { start searching things using } \\
\text { these popular search } \\
\text { engines. OER can also be } \\
\text { easily found using these } \\
\text { tools, especially by using the } \\
\text { advance features they } \\
\text { provide. }\end{array}$ \\
\hline $\begin{array}{l}\mathrm{CC} \\
\text { Search } \\
\text { tools }\end{array}$ & $\begin{array}{l}\text { http://search.creativecommons } \\
\text {.org/ }\end{array}$ & $\begin{array}{l}\text { A creative commons (CC) } \\
\text { search tool. Although, this } \\
\text { tool is specifically designed } \\
\text { to find content with CC } \\
\text { licenses, it is advisable that } \\
\text { users of the site should } \\
\text { check as not all search } \\
\text { results are under CC } \\
\text { license. }\end{array}$ \\
\hline $\begin{array}{l}\text { Video } \\
\text { Search } \\
\text { Tools }\end{array}$ & $\begin{array}{l}\text { http://www.youtube.com } \\
\text { http: / / www.vimeo.com } \\
\text { http: / / archive.org/details/mov } \\
\text { ies } \\
\text { http: / / www.ted.com/ } \\
\text { http: / / cc.aljazeera.net/ }\end{array}$ & $\begin{array}{l}\text { Video database sites that } \\
\text { allow people to } \\
\text { find and share videos. The } \\
\text { videos can be of various } \\
\text { licenses, but many videos } \\
\text { with CC licenses can be } \\
\text { easily found there by } \\
\text { applying built-in filter } \\
\text { provided in the site. }\end{array}$ \\
\hline
\end{tabular}




\begin{tabular}{|c|c|c|}
\hline $\begin{array}{l}\text { Catego } \\
\text { ries }\end{array}$ & URL & Annotation \\
\hline $\begin{array}{l}\text { Image } \\
\text { Search } \\
\text { Tools }\end{array}$ & $\begin{array}{l}\text { http: / /www.google.com/adva } \\
\text { nced_image_search } \\
\text { http: / /www.pixabay.com } \\
\text { http: / /openclipart.org/ }\end{array}$ & $\begin{array}{l}\text { Finding images using this } \\
\text { tool has never been easier. } \\
\text { Though not all images found } \\
\text { are free to use but by using } \\
\text { built-in filters in the sites, } \\
\text { one can easily find the free } \\
\text { ones. }\end{array}$ \\
\hline $\begin{array}{l}\text { Open } \\
\text { Textboo } \\
\text { k Search }\end{array}$ & $\begin{array}{l}\text { http: / /www.collegeopentextbo } \\
\text { oks.org/ } \\
\text { http: / /openstaxcollege.org/ } \\
\text { http: / / projects.siyavula.com/ } \\
\text { http: / /www.ck12.org/ } \\
\text { https: / /www.boundless.com/ }\end{array}$ & $\begin{array}{l}\text { These sites provide access to } \\
\text { open textbooks developed } \\
\text { and peer reviewed by } \\
\text { educators from around the } \\
\text { world. Although most of the } \\
\text { books are science and } \\
\text { mathematics-related, they } \\
\text { can still be used for language } \\
\text { teaching purposes. }\end{array}$ \\
\hline $\begin{array}{l}\text { OER } \\
\text { Database }\end{array}$ & $\begin{array}{l}\text { http: / /www.merlot.org/ } \\
\text { http: / / cnx.org/ } \\
\text { http: / / oerconsortium.org/ } \\
\text { http: / /www.oercommons.com } \\
\text { http: / / www.openculture.com }\end{array}$ & $\begin{array}{l}\text { These websites are databases } \\
\text { for OER. The content } \\
\text { ranges from full courses, to } \\
\text { images, video, recorded } \\
\text { lectures, lesson strategies } \\
\text { etc. }\end{array}$ \\
\hline $\begin{array}{l}\text { Open } \\
\text { Courses }\end{array}$ & $\begin{array}{l}\text { http: / / oeru.org } \\
\text { http: / / www.coursera.org } \\
\text { http: / / www.edx.org } \\
\text { https: / / www.futurelearn.com/ } \\
\text { http: / / online.stanford.edu/cou } \\
\text { rses }\end{array}$ & $\begin{array}{l}\text { Learning with world class } \\
\text { universities, accessing world } \\
\text { class knowledge and experts } \\
\text { is not difficult today through } \\
\text { these websites. Learners can } \\
\text { easily choose from various } \\
\text { available free courses and } \\
\text { obtain certification when } \\
\text { they complete the course. }\end{array}$ \\
\hline $\begin{array}{l}\text { Learning } \\
\text { Manage } \\
\text { ment } \\
\text { System }\end{array}$ & $\begin{array}{l}\text { httt: / /www.schoology.com } \\
\text { http: / /www.myhaikuclass.com } \\
\text { http: / /www.coursesites.com } \\
\text { http: / / www.edmodo.com }\end{array}$ & $\begin{array}{l}\text { To start developing online } \\
\text { learning, one will need } \\
\text { these websites. They } \\
\text { provide free access for } \\
\text { registered users to instantly } \\
\text { create their online courses }\end{array}$ \\
\hline
\end{tabular}




\begin{tabular}{|l|l|l|}
\hline $\begin{array}{l}\text { Catego } \\
\text { ries }\end{array}$ & URL & Annotation \\
\hline & & $\begin{array}{l}\text { or just online elements of } \\
\text { their face-to-face courses. } \\
\text { The features offered here } \\
\text { include } \\
\text { materials/assignment } \\
\text { organizers, grade books, } \\
\end{array}$ \\
& & $\begin{array}{l}\text { quiz creators, students } \\
\text { learning statistics, } \\
\text { attendance etc. }\end{array}$ \\
\hline
\end{tabular}

The sites in the tables only provide tools, and they are worthless when users do not know what to do with them. Instead, it is even possible that the online tools would just cause confusion for users if the users do not have a clear plan of how to engage with them. In the same vein, Son (2011) advises that teachers should be "knowledgeable and skillful enough to guide students when and how to use which (online) tools for effective language learning". In short, whatever technology is available out there; it is just a tool to assist teaching and learning. Teachers and students should be well educated and trained on how to make use of it effectively and efficiently for better teaching and learning experiences.

\section{A SAMPLE POSSIBLE SCENARIO FOR USING OER IN A TEACHING LEARNING PROCESS}

The sites listed in Table 3 help OER seekers to find their possibly expected resources that they can use for their teaching or learning. The sites are just to give easy access to OER which are nowadays of various forms and types offering various features that helps people to be more creative, more attentive, more motivated and more explorative when learning in this digital era. This is made possible partly by the advance of web 2.0 technologies where people are given more freedom to access tools, materials, and support whenever they need ones. The web 2.0 technologies nowadays have given more possibilities for people to access valuable learning and teaching resources and tools by using only a web browser. 
Lets' take an example of a video sharing website like YouTube. This web 2.0 website enables users not only to view but also to share and even discuss video contents over the web. Various contents are shared, searched and viewed by people all over the world. For teachers finding teaching materials are nowadays relatively easy because many types of videos of various themes are shared by people around the world. When a teacher wants to explain what a cappuccino is and how to make one, $\mathrm{He} / \mathrm{she}$ can just search for the video about it and share to students. Thus, no need for the teachers to explain or create his/her own video just to explain about cappuccino to the students.

Another example would be when a student is to make presentation for what he/she has been reading. The student is to present it in the form of info graphic, video animation, or even just a mind map. The teachers can then just refer the students to the online tools available nowadays for free to create an info graphic such as http://piktochart.com, http://visual.ly, or http://www.easel.ly/. There, they will create an info graphic for what they have read and make visual presentation. If students want to do video animation, they can try online tools such as http://www.videoscribe.co or http://www.powtoon.com. Alternatively, they can use mind map authoring tools which are available online such as http://popplet.com or https: / / bubbl.us/

A more complex scenario for using OER can be as follows. Teacher created an online space for interacting with students in a free learning management system (LMS) such http://www. schoology.com, http://coursesites.com, http:// edmodo.com, http://myhaikuclass.com etc. Those LMS are free to use but will be more functional if the user willing to pay for improved features or services. Then, students are to register on the LMS and start reading materials presented there. They will then share their opinion on the available discussion board within the LMS. They can ask questions there, help others by responding to their posts, or even make a digital portfolio there. In the LMS students can also work on a given quizzes where later the teachers can automatically grade the student's objective tests. The teacher later makes a direct correction on students 
submission online, as well as give the students work a feedback whenever necessary.

\section{REFERENCES}

Atkins, D. E., Brown, J. S., \& Hammond, A. L. (2007). A review of the open educational resources (OER) movement: Achievements, challenges, and new opportunities: Creative common.

Caswell, T., Henson, S., Jensen, M., \& Wiley, D. (2008). Open Content and Open Educational Resources: Enabling universal education. The International Review of Research in Open and Distributed Learning, 9(1).

Commons, C. (2016). About the licenses. Retrieved from https: / / creativecommons.org/licenses /

Friesen, N. (2013). Realising the open in open educational resources: Practical concerns and solutions. In R. McGreal, W. Kinuthia, \& S. Marshall (Eds.), Open educational resources: Innovation, research and practice (pp. 79-90). Vancouver: Commonwealth of Learning.

Hodgkinson-Williams, C. (2010). Benefits and challenges of OER for higher education institutions. Paper presented at the OER Workshop for Heads of Commonwealth Universities, Cape Town, Africa. Retrieved from http: / / www.col.org/SiteCollectionDocuments/OER Benefit sChallenges presentation.pdf.

Matkin, G. W. (2010). The open educational resources movement: current status and prospects.

McGill, L. (2013). What are open educational resources. Retrieved from

https: / / openeducationalresources.pbworks.com/w/page/248 36860/What are Open Educational Resources

OECD. (2007). Giving knowledge for free: The emergence of open educational resources. Paris: OECD Publishing.

Thakrar, J., Wolfenden, F., \& Zinn, D. (2009). Harnessing Open Educational Resources to the Challenges of Teacher Education 
in Sub-Saharan Africa. The International Review of Research in Open and Distributed Learning, 10(4).

Wheeler, S. (2010). What's so good about open educational resources. Paper presented at the UNESCO's OER Conference, Windhoek, Namibia. Retrieved from http://www.col.org/SiteCollectionDocuments/OER WhatIs Good Wheeler.pdf.

White, D., Manton, M., \& Warren, N. (2011). Open educational resources (OER): The value of reuse in higher education. Oxford: Creative Commons. 